\title{
Purpura Fulminanis
}

\section{Mahmoud Khalifa Marzouq ${ }^{1}$, Khadiga Ahmed Ismail2,3*, Ahmed Mahmoud Khalifa ${ }^{4}$ and Osama Mahmoud Khalifa $^{5}$}

${ }^{1}$ Consaltant of Dermatology and Venereology, King Faisal specialized Hospital, Saudi Arabia

${ }^{2}$ Department of Laboratory Medicine, Taif University, Saudi Arabia

${ }^{3}$ Department of Parasitology, Ain-Shams University, Egypt

${ }^{4}$ Department Forensic and Toxicology, Ain-Shams University, Egypt

${ }^{5}$ Faculty of Medicine, Ain-Shams University, Egypt

Submission: December 05, 2018; Published: December 20, 2018

*Corresponding author: Khadiga Ahmed Ismail, Department of Laboratory Medicine \& Department of Parasitology, King Faisal specialized Hospital \& Ain-Shams University, Saudi Arabia

\section{Abstract}

Purpura Fulminanis (PF) is an emergency progressive thrombotic disorder in which there is skin necrosis, Disseminated Dntravascular Coagulation (DIC) and multiorgan failure. It may complicate severe sepsis or may occur as an autoimmune response to other infection as varicella. Also, it may associate with severe heritable deficiency of protein $\mathrm{C}$ or protein S. PF is a rapidly fatal disease, so it needs rapid diagnosis and management promptly. We present a case of purpura fulminanis who died, unfortunately, after 8 days due to severe sepsis.

Keywords: Purpura Fulminanis; Disseminated Dntravascular Coagulation; Coronary Artery Bypass Grafting; Disseminated Intravascular Coagulation; Intensive Care Unit; Laboratory Investigations; Neutrophilic predominance; creatinine; Histological Findings; Methylprednisolone; Immunoglobulin; Warfarin-Induced Skin Necrosis; Warfarin-induced skin; pathophysiology; Thrombotic Thrombocytopenic purpura

Abbreviations: PF: Purpura Fulminanis; DIC: Disseminated Dntravascular Coagulation; CABG: Coronary Artery Bypass Grafting; DIC: Disseminated Intravascular Coagulation; ICU: Intensive Care Unit; PTT: Partial thromboplastin time; WBC: White blood cell count

\section{Case Report}

Male patient, 73years old, presented to the Emergency Department with coffee ground vomiting ( 5 times) associated with abdominal pain and melena. He was diabetic, hypertensive, and had chronic obstructive pulmonary disease and had past history

\section{On Examination}

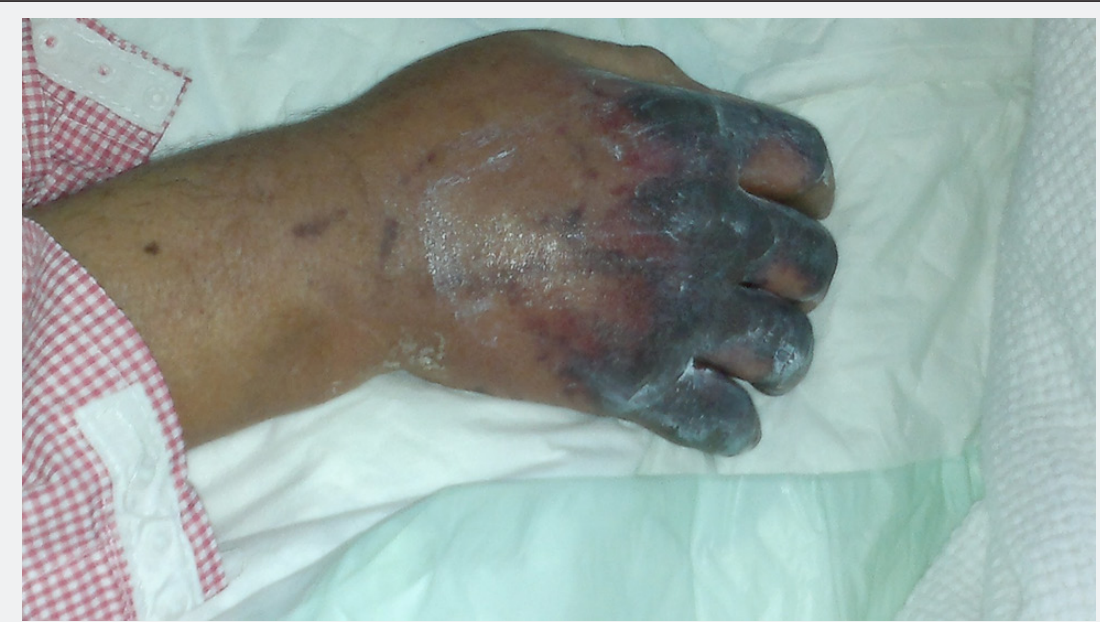

Figure 1: Showed purpuric blackish edematous lesions over Right hand.

of Coronary Artery Bypass Grafting (CABG). After three days, he developed septic shock which was associated with coma, purpuric rash and overt Disseminated Intravascular Coagulation (DIC), and renal impairment. He was managed by fluid resuscitation and intubation and was transmitted to Intensive Care Unit (ICU). 


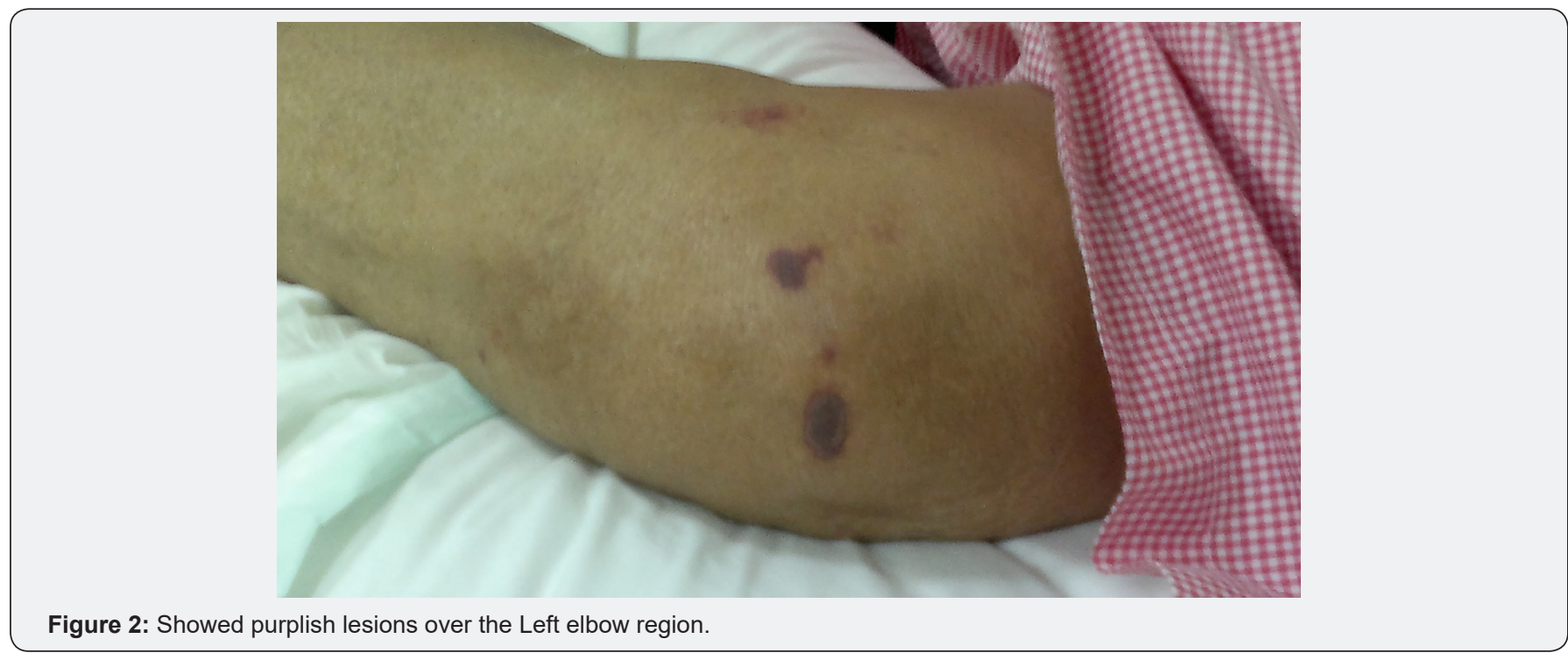

He was afebrile, his temperature was $36.8^{\circ} \mathrm{C}$, his blood pressure was $104 / 68 \mathrm{mmHg}$ with a heart rate of 71 beats/minute, respiratory rate of 17 breaths/minute, and oxygen saturation of $94 \%$ in room temperature air. He had generalized deep purpuric lesions on both hands, upper and lower extremities, some of lesions were blackish purpuric in color with tense blisters as in dorsum surfaces of both hands, as shown in Figure $1 \& 2$.

\section{Laboratory Investigations}

\section{As regard his complete blood count}

The clinically significant results are as follows:

White blood cell count (WBC) of $6.97 \mathrm{k} / \mu \mathrm{L}(\mathrm{N})(\mathrm{n} 4-10 \mathrm{k} /$ $\mu \mathrm{L}$ ), with a neutrophilic predominance of $93.3 \%$ (n40-80\%), Red blood cell count (RBC) of $4.02 \mathrm{M} / \mu \mathrm{L}(\mathrm{L})(\mathrm{n} 4.5-505 \mathrm{M} / \mu \mathrm{L})$ with a hemoglobin of $9.9 \mathrm{gm} / \mathrm{dl}(\mathrm{L})$, hematocrit of $32.90 \%$ (L) (n40-50\%), Platelet count of $269 \mathrm{~K}$

\section{Histological Findings}

$/ \mu \mathrm{L}(\mathrm{N})(\mathrm{n} 150-410 \mathrm{~K} / \mu \mathrm{L})$.

\section{As regard his chemistry}

His random glucose of $322 \mathrm{mg} / \mathrm{dL}$ (high) (n70-140mg/dL), blood urea of $154.60 \mathrm{mg} / \mathrm{dL}$ (high critical) (n $8.6-10.20 \mathrm{mg} / \mathrm{dL}$ ), creatinine of $2.99 \mathrm{mg} / \mathrm{dL}$ (high) (n $8.6-10.20 \mathrm{mg} / \mathrm{dL}$ ), normal SGOT (AST) $(22 \mu / \mathrm{L})(\mathrm{n} 0-35 \mu / \mathrm{L})$, normal SGPT (ALT) $(14 \mu / \mathrm{L})(\mathrm{n}$ $0-41 \mu / \mathrm{L})$, normal bilirubin (total) $(0.476 \mathrm{mg} / \mathrm{dL})(\mathrm{n} 0-1.1 \mathrm{mg} / \mathrm{dL})$, low total protein $(5.93 \mathrm{~g} / \mathrm{dL})(\mathrm{n} 6.6-8.7 \mathrm{~g} / \mathrm{dL}$ ) and low albumin of $3.67 \mathrm{~g} / \mathrm{dL}$ (L) (n3.97-4.94g/dL), low chloride (92.20mmol/L) (n98$107 \mathrm{mmol} / \mathrm{L})$, low sodium (132mmol/L) (n135-151mmol/L), and High critical potassium $(8.02 \mathrm{mmol} / \mathrm{L})(\mathrm{n} 3.4-5.1 \mathrm{mmol} / \mathrm{L})$.

\section{As regard coagulation profile}

Partial thromboplastin time (PTT) was (84.40 sec.) (high) (n26-40 seconds), ThromboPlastin time (PT) of (16.60 sec.) (high) (n11-14.5 seconds), and INR of $1.30 \%$ (high) (n0.8-1.2\%).

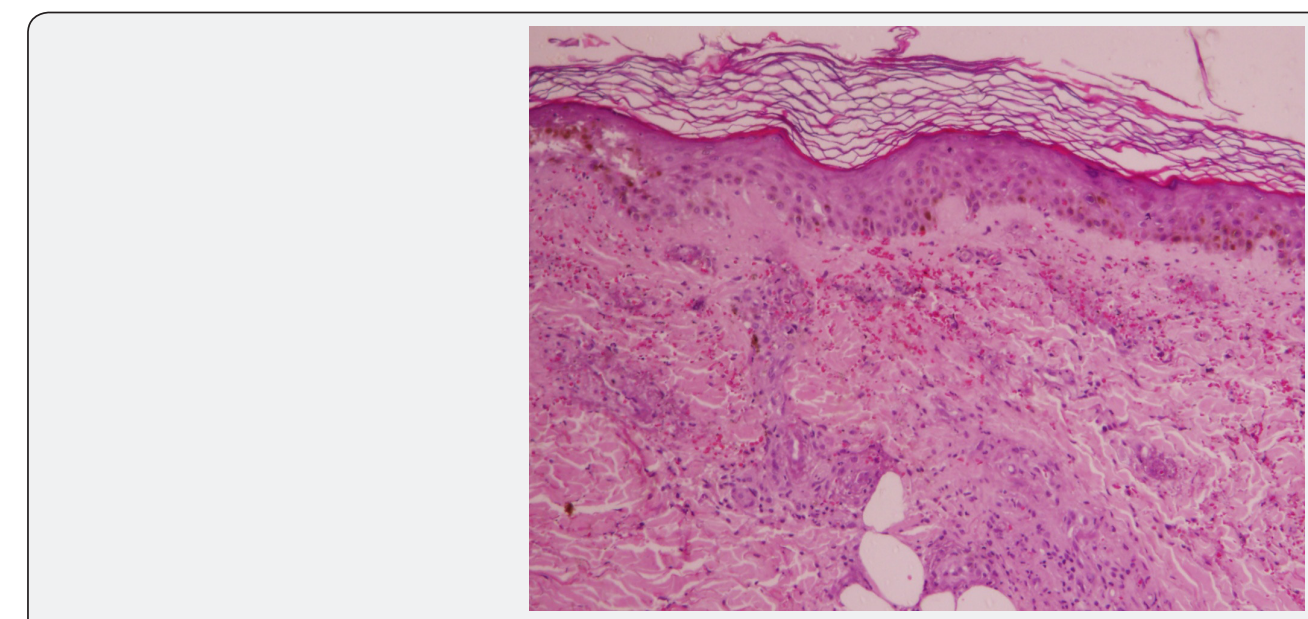

Figure 3: Low power microscopic picture fibrinoid necrosis of the vessel walls, and extravasations of red blood cells, and the epidermis normal histology.

Sections examined from skin biopsy showed dermis with small blood vessels surrounded by neutrophils, neutrophils dust, fibrinoid necrosis of the vessel walls, and extravasations of red blood cells. The overlying epidermis showed normal histology, as shown in Figure 3 \& 4. 


\section{Juniper Online Journal of Dermatology \& Cosmetics}

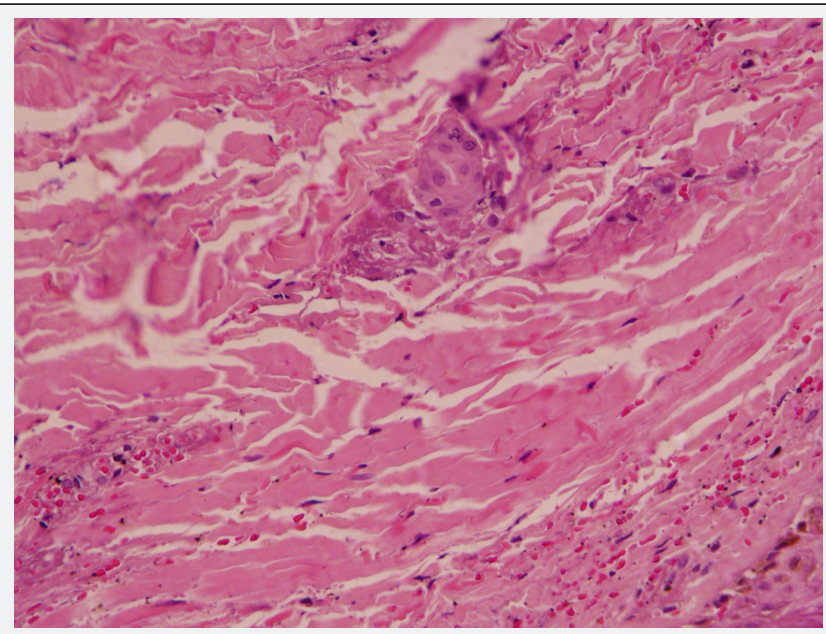

Figure 4: High power microscopic picture showed small blood vessels surrounded by neutrophils, neutrophils dust, fibrinoid necrosis of the vessel walls, and extravasations of red blood cells.

\section{Discussion}

The patient was admitted at the ICU, and his high blood sugar was controlled by insulin, his purpura was treated by the rheumatologist with methylpredisolone $750 \mathrm{mg}$ i.v. daily for three days, and was treated by heparin and broad-spectrum antibiotics, but unfortunately, he died due to severe sepsis after 8 days. Although, the histopathological examination suggested diagnosis of leuckcytoclastic vasculitis, the case was presented clinically as a purpura fulminans, and the methylpredisolone $750 \mathrm{mg}$ i.v. daily for three days which was prescribed by the rheumatologist was wrong because it flared the sepsis, and the best medication was fresh plasma and immunoglobulin G.

\section{Differential diagnosis}

\section{Purpura fulminans}

Purpura Fulminans (PF) is a life-threatening disorder of acute onset characterized by cutaneous haemorrhage and necrosis caused by disseminated intravascular coagulation and dermal vascular thrombosis. Three distinct categories can be identified: inherited or acquired abnormalities of protein $\mathrm{C}$ or other coagulation systems, acute infectious PF, and idiopathic [1]. Its cardinal manifestations are presence of circumscribed ecchymosis of skin and symmetrical gangrene of the extremities with coagulation abnormalities suggestive of disseminated intravascular coagulation [2]. Late findings in necrotic areas are the formation of vesicles and bullae, which mark the development of haemorrhagic necrosis, and finally firm eschar, which ultimately sloughs. The distal extremities are often most severely involved, usually in a symmetric manner, probably due to fewer collateral channels for tissue perfusion, and the relatively greater impact of circulatory collapse on perfusion of distal vascular beds [3].

Development of systemic consumptive coagulopathy is a defining feature of $\mathrm{PF}$, which distinguishes it from other forms of skin necrosis due to dermal vascular occlusion such as warfarin or heparin induced skin necrosis, thrombotic thrombocytopenic purpura, cryoglobulinaemia, antiphospholipid syndrome, or paroxysmal nocturnal haemoglobinuria. Fibrinogen, coagulation factors (factor V and VIII), and platelets are consumed in ongoing thrombosis and fibrinolysis. Prothrombin time, partial thromboplastin time are prolonged; fibrin degradation products are elevated, and protein C, protein S and antithrombin III are reduced. The histopathological hallmarks of PF are dermal vascular thrombosis and secondary haemorrhagic necrosis [4], which are identical to Schwartzman reaction [5]. Vasculitis, including a perivascular neutrophilic infiltrate, is a characteristic feature of acute infectious PF, which distinguishes it from other forms of PF.

\section{Leuckcytoclastic vasculitis}

Leukocytoclastic vasculitis (LCV), also called hypersensitivity vasculitis, is a small-vessel vasculitis its incidence rate is about 30 cases per million people per year and affect men and women in equal numbers $[6,7]$. The skin is the organ most commonly involved by LCV and its presentation is a painful, burning rash predominantly in the lower extremities, with up to one-third of patients presenting with trunk and upper extremity involvement. [3] The most common skin manifestation of LCV is palpable purpura [8]. Other skin manifestations include maculopapular rash, bullae, papules, plaques, nodules, ulcers, and livedo reticularis. Patients with LCV may also present with arthralgias or arthritis involving the knees or ankles [9].

\section{Meningococcemia}

The clinical pattern of meningococcemia varies. Persons with meningococcal disease may present with a nonspecific prodrome of cough, headache, and sore throat. After a few days of upper respiratory symptoms, the temperature rises abruptly, often after a chill. malaise, weakness, myalgia, headache, nausea, vomiting, and arthralgia are common presenting symptoms. A skin rash, which is essential for recognizing meningococcemia, is the characteristic manifestation. The skin rash may advance from a few ill-defined lesions to a widespread petechial eruption within a few hours. Meningococcemia's potential rapidity of progression cannot be stressed enough. In fulminant meningococcemia, a hemorrhagic eruption, hypotension, and cardiac depression, as well as rapid 


\section{Juniper Online Journal of Dermatology \& Cosmetics}

enlargement of petechiae and purpuric lesions, may be apparent within hours of the initial presentation [10].

\section{Warfarin-Induced Skin Necrosis}

Warfarin inhibits the activation of vitamin K-dependent clotting factors II, VII, IX, and X and the anticoagulant proteins C and S [11-13]. Warfarin-induced skin necrosis is a rare $(0.01 \%$ $0.1 \%$ ) but serious complication that usually occurs within the first several days following warfarin initiation, although case reports have described this phenomenon later in therapy as well [12-15]. This adverse drug reaction appears to be associated with larger doses of warfarin [13]. The pathophysiology is not well understood; however, it is theorized that this complication is due to the initial procoagulant state that warfarin causes, leading to the formation of fibrin clots within the microvasculature. These blood clots cause interruption in blood supply to the skin, resulting in necrosis. The general progression of warfarin-induced skin necrosis is as follows: pain and erythema; petechial hemorrhages; red, purple, blue, or black discoloration; necrosis; and hemorrhagic blisters and/or bullae. Early recognition of symptoms and treatment are vital to preventing substantial morbidity associated with warfarininduced skin necrosis; however, due to its rare occurrence, appropriate treatment has not been well established [12].

\section{Thrombotic thrombocytopenic purpura}

Thrombotic thrombocytopenic purpura (TTP) is a rare blood disorder characterized by clotting in small blood vessels (thromboses), resulting in a low platelet count [16]. In its fullblown form, the disease consists of microangiopathic hemolytic anemia, thrombocytopenic purpura, neurologic abnormalities, fever and Renal disease [17].

TTP can affect any organ system, but involvement of the peripheral blood, the central nervous system, and the kidneys causes the clinical manifestations. Patients with TTP typically report an acute or subacute onset of symptoms related to neurologic dysfunction, anemia, or thrombocytopenia. The neurologic manifestations include alteration in mental status, seizures, hemiplegia, paresthesias, visual disturbance, and aphasia. Fatigue may accompany the anemia. Severe bleeding from thrombocytopenia is unusual, although petechiae are common $[18,19]$.

\section{Conclusion}

Purpura fulminanis manifestations are confusing with many diseases, so we should differentiate it promptly from other diseases to avoid misdiagnosis, delay management, mistreatment, and sudden death as occurred in our presented case.

\section{References}

1. Adcock DM, Bronza JP, Marlar RA (1990) Proposed classification and pathologic mechanism of purpura fulminans and skin necrosis. Semin Thromb Hemost 16(4): 333-340.
2. Hautekeete ML, Berneman ZN, Bieger R, Stevens WJ, Bridts, et al. (1986) Purpura fulminans in pneumococcal sepsis. Arch Intern Med 146(3): 497-499.

3. Darmstadt GL (1998) Acute infectious purpura fulminans: pathogenesis and medical management. Ped Dermatol 15(3): 169-183.

4. Adcock DM, Hicks MJ (1990) Dermatopathology of skin necrosis associated with purpura fulminas. Semin Thromb Hemost 16(4): 283 292.

5. Bronza JP (1990) Schwartzman reaction. Semin Thromb Hemost 16(4): 326-333.

6. Hussain N, Mustafa U, Davis J, Thakkar S, Ali AM, et al. (2013) Indomethacin-related leukocytoclastic vasculitis: a case report and review of literature. Case Rep Dermatol 5(1): 33-37.

7. González-Gay MA, García-Porrúa C (1999) Systemic vasculitis in adults in northwestern Spain,1988-1997. Clinical and epidemiologic aspects. Medicine (Baltimore) 78(5): 292-308.

8. Brown K, Martin J, Zito S (2010) Severe leukocytoclastic vasculitis secondary to the use of naproxen and requiring amputation: a case report. J Med Case Rep 4: 204.

9. Martinez-Taboada VM, Blanco R, Garcia-Fuentes M, RodriguezValverde V (1997) Clinical features and outcome of 95 patients with hypersensitivity vasculitis. Am J Med 102(2): 186-191.

10. Mahmud H Javid, John L Bruch, Shadab H Ahmed, Francisco T (2018) Meningococcemia Clinical Presentation. Medscape, 28

11. McKnight JT, Maxwell AJ, Anderson RL (1992) Warfarin necrosis. Arch Fam Med 1(1):105-108.

12. Nazarian R, Van Cot E, Zembowicz A, Duncan,LM (2009) Warfarininduced skin necrosis. J Am Acad Dermatol 61(2): 325-332.

13. Chan YC, Valenti D, Mansfield AO, Stansby (2000) Warfarin induced skin necrosis. Br J Surg 87(3): 266-272

14. Kumar M, Abrina V, Chittimireddy S (2012) Coumadin-induced skin necrosis in a 64-year-old female despite LMWH bridging therapy. Am J Case Rep 13: 157-159.

15. Alves D, Chen I (2002) Warfarin-induced skin necrosis. Hosp Physician 38: 39-42.

16. Joly BS, Coppo P, Veyradier A (2017) Thrombotic thrombocytopenic purpura. Blood 129(21): 2836-2846.

17. Tsai HM (2013) Thrombotic thrombocytopenic purpura and the atypical hemolytic uremic syndrome: an update. Hematol Oncol Clin North Am 27(3): 565-584.

18. Ferrari S, Mudde GC, Rieger M, Veyradier A, Kremer Hovinga JA, et al. (2009) IgG-subclass distribution of anti-ADAMTS13 antibodies in patients with acquired thrombotic thrombocytopenic purpura. J Thromb Haemost7(10): 1703-1710

19. Mariotte E, Azoulay E, Galicier L, Rondeau E, Zouiti F, et al. (2016) Epidemiology and pathophysiology of adulthood-onset thrombotic microangiopathy with severe ADAMTS13 deficiency (thrombotic thrombocytopenic purpura): a cross-sectional analysis of the French national registry for thrombotic microangiopathy. Lancet Haematol 3(5): e237-e245. 
(C) This work is licensed under Creative (cC) DOI: 10.19080/JOJDC.2018.01.555564

\section{Your next submission with Juniper Publishers will reach you the below assets}

- Quality Editorial service

- Swift Peer Review

- Reprints availability

- E-prints Service

- Manuscript Podcast for convenient understanding

- Global attainment for your research

- Manuscript accessibility in different formats ( Pdf, E-pub, Full Text, Audio)

- Unceasing customer service

Track the below URL for one-step submission https://juniperpublishers.com/online-submission.php 